The location for meteorological observations in the ISC "Observatory" is unique. In terms of scientific research, we will have continuous monitoring of atmosphere elements and of the natural environment as a whole at an altitude of over $2000 \mathrm{~m}$ a.s.l. Meteorological research at this station is reasonable and will be the main task of the Observatory. Also, the results of the observations will have practical application from day to day, such as timely warning of avalanche danger or as a search and rescue service. Given the great importance of this mountain ridge in terms of climate, as well as to understand the physical and geographical processes in the whole region, it is worth to use comprehensive researches of its environment. Along with the observations made in other parts of the Carpathians, it will allow us to understand better the climatic features as well as the whole environment of the Carpathian regions.

Key words: Chornohora, Pip Ivan, Observatory, climate, meteorology.

http://doi.org/10.17721/1728-2721.2019.74.15

UDC 504.06

\author{
A. Sholokhova ${ }^{1}, M S c$ student, \\ O. Tsibernaja ${ }^{2}, M S c$ student, \\ V. Mykhaylenko', Ph.D. chemistry Assoc. Professor, \\ J. Burlakovs ${ }^{3}, \mathrm{PhD}$, \\ V. Kuusemets ${ }^{2}, \mathrm{PhD}$ Professor, \\ K.-M. Pehme ${ }^{2}$, PhD student, \\ M. Kriipsalu², PhD Professor \\ 1) Taras Shevchenko National University of Kyiv, Ukraine, \\ 2) Estonian University of Life Sciences, Tartu, Estonia, \\ ${ }^{3)}$ Linnaeus University, Växjö, Sweden
}

\title{
PILOT-SCALE METHANE DEGRADATION BIOCOVER AT OPERATING LANDFILL
}

A landfill is a large bioreactor, in the body of which landfill gases are generated due to anaerobic degradation of organic material. According to European legislation, the emission of methane, one of the landfill gases, should be kept to a minimum as methane is a greenhouse gas and has a significant impact on our climate. With large volumes, methane can be used for energy production, but if the collection is uneconomic, an attractive option would be to cover the landfill with a bioactive layer to degrade methane in-situ. In operational Uikala sanitary landfill, Estonia, where active gas collection system exists, it was found that uncaptured gas could be degraded in bioactive cover layer. To check whether such cover layer could be built from fine fraction after mechanical biological treatment (MBT), two experimental cells were constructed (0-20 mm and 0-40 mm fractions). The paper presents the design of experimental cells, a description of materials for construction and construction process, and preliminary results. Measurement system was installed in both cells: gas wells at eight depths and on three locations on surface. Three-level lysimeters were installed to determine water balance. Research is planned for two years with monthly gas sampling. The objective of the work is proving which of the MBT fractions, 0-20 or 0-40 mm, function better for methane degradation. Confirmation of the methane degradation efficiency in fine MBT fraction is important not only from the ecological point of view. The use of a fine fraction as a material for methane degradation layer would reduce the cost of processing this fraction and become a good example to a circular economy since the landfill would be recultivated using its own resources.

Keywords: Landfill gas, MBT fine fraction, Emission, Methane degradation layer, Landfill cover, Lysimeter

Introduction. Human activity is contributing to increasing the concentration of greenhouse gases in the atmosphere. This results in significant warming of the earth's surface and other associated changes in climate. In addition to industrial and agricultural activities, large contributors of greenhouse gases are landfills. Degradation of organic waste in landfill releases methane a greenhouse gas that is 23 times more effective at trapping heat in the atmosphere than carbon dioxide. Methane discharge accounts as $14 \%$ of the world GHG emissions [1]. As part of the suite of measures to improve the sustainability of waste management and climate system, the Landfill Directive (1999/31/EC) introduces requirements on member states to reduce the methane emissions. In order to comply with these requirements, landfill gas collected and used for energy production or flared. However, gas is produced at a stable rate typically for about 20 years [4] and then the amount of gas gradually decreases. Eventually collection of methane becomes economically unprofitable. An attractive option to destroy methane gas even then would be to cover the landfill with a bioactive layer to degrade methane in-situ. Biocover may be made of various organic-rich materials, including fine fraction from mechanical-biological-treatment (MBT). The properties of such materials, however, have to be confirmed by field trail.

Theoretical background. According to the R. Hanson and T. Hanson [3] scientific research methane can be oxidized by methanotrophic bacteria. M. Scheutz [10], G. Pedersen [7], Y. Philopoulous [9] consider that methanotrophic bacteria are ubiquitous soil bacteria, but long lag phases towards reaching high $\mathrm{CH}_{4}$ oxidation rates are found especially in mineral materials. Therefore the focus in recent years has been on methane degradation by using organic materials. Studies of organic biocovers are described in scientific papers of $\mathrm{H}$. Hilger and M. Humer [4], M. Barlaz [1].

M. Humer and P. Lechner [5] based on the testing of 25 different materials propose several physical and chemical parameters for biocover materials, including organic content, moisture and $\mathrm{pH}$ value. According to various criteria, fine fraction from mechanical-biological-treatment (MBT) can be a good material for biocover. First biocover of its kind in Estonia was designed for Kudjape landfill [8] as a part of recultivated project, and was studied in detail.

Purpose. This study aims to prove that MBT fine fraction is fit-to-use as functional material for methane degradation layer. Another objective was to study how the methane degradation window works at operating landfill.

The main sub-objectives of the project are to:

- prove that $\mathrm{CH}_{4}$ is present in cell

- prove that $\mathrm{CH}_{4}$ is not escaping to atmosphere

- prove that gas is degraded in the cell

- prove that environmental conditions are favorable for microbial degradation

- measure composition of gases

- demonstrate dynamics in gas composition over time

- perform microbiological analysis

Monitoring of the cells is planned within two years at intervals of every month.

Materials and methods. Uikala landfill is located in IdaVirumaa, Estonia, five kilometres to the north of the town Jõhvi and four kilometres to the south of the Gulf of Finland. The landfill that met the requirements of the EU Landfill Directive (1999/31/EC) commenced on January 1, 2002. 
The place for the landfill was chosen so that the negative impact on the environment was minimal. The landfill is surrounded by forest, which helps to minimize the migration of dust and noise to residential areas, approximately 1100 meters from the landfill site. The landfill area is surrounded by drainage trenches and a fence. Disposal area has a watertight bottom liner, and leachate is treated by reverses osmosis. In 2008 , the waste sorting line was built at Uikala landfill. In this building, sorting of mixed packaging, paper and cardboard, as well as household waste are takes place. From the mixed wastes are sorted out paper, cardboard, metal, plastic, polyethylene, glass and wood. Unsuitable materials are disposed at the landfill. There are three disposal areas, one of which has already been completed. Landfill gas is collected by active gas collection system, cleaned with a carbon filter and pumped to a co-generation plant where it is used for the production of electricity and heat. The electricity is sold to the grid and surplus heat is used for heating landfill facilities, garages, and office building.

Two experimental cells $(0-20 \mathrm{~mm}$ and $0-40 \mathrm{~mm}$ fractions) were constructed at the side of the landfill so as not to interfere everyday work of landfill. The size of each experimental cells is 10 by 10 meters.

Each of cells consists of two basic layers: methane distribution layer and methane degradation layer (Fig. 2). Gravel was chosen as materials for the methane distribution layer. Approximate amount of spent gravel ranges from 30 to $50 \mathrm{~m}^{3}$ per cell. Main purpose of this layer is distributing gas evenly into the top-layer, where methane is degraded [8]. The height of the mineral layer is 0,3 to $0,5 \mathrm{~m}$.

Two methane degrading layers were built using fine fractions $40 \mathrm{~mm}$ at the first cell and $20 \mathrm{~mm}$ at the second one. Approximate amount of MBT is $220 \mathrm{~m}^{3}$ per cell. The MBT fractions were not used for any purpose before, so its applicability as a construction material for the methanedegrading layer is important for both environmental and economic prospective.

In order to prevent horizontal migration of methane and ensuring the passage of gas through the experimental layers, the PE foil isolation and temporary barriers were built around the cells (Fig. 1).

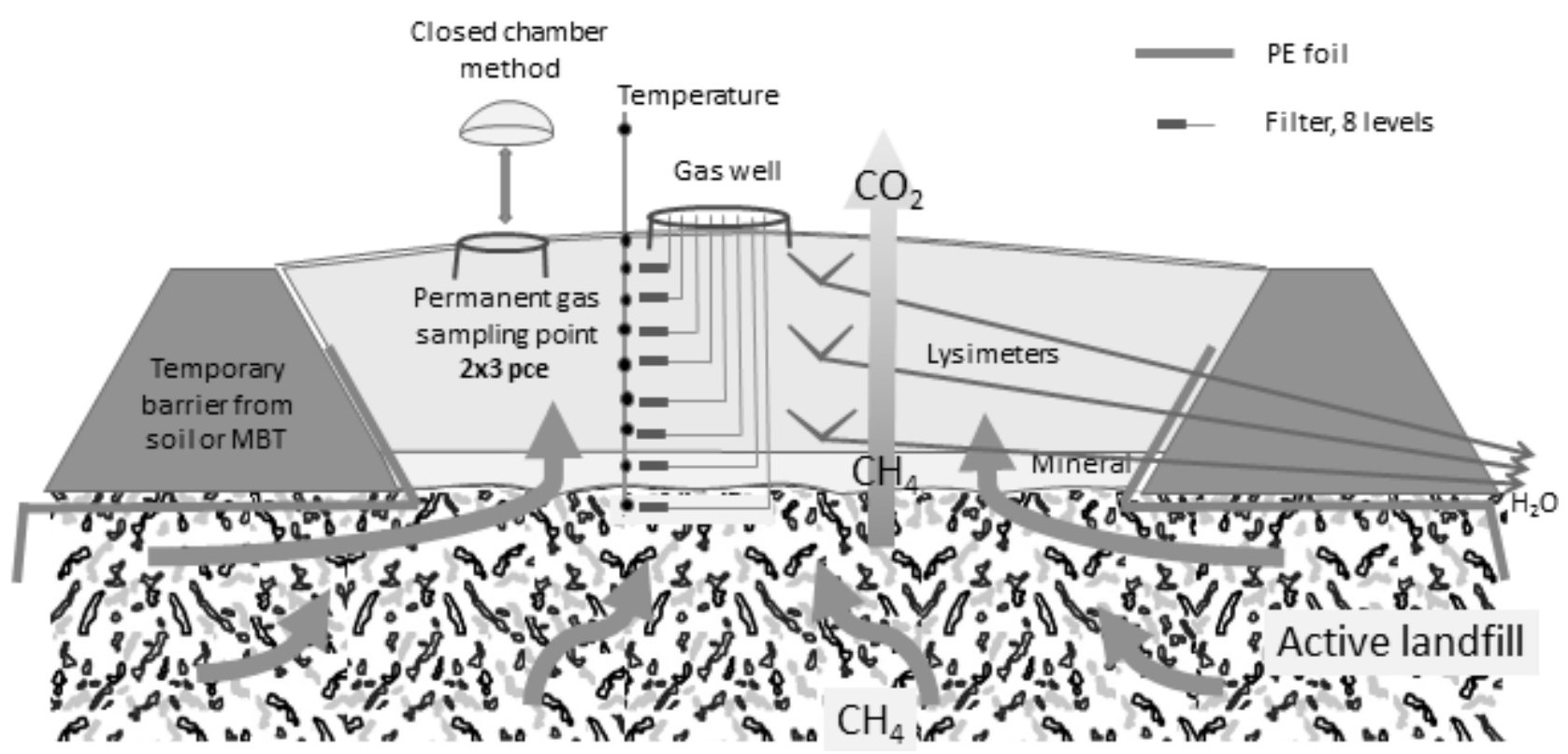

Fig. 1. General scheme of experimental cells

8-level gas well was installed in both cells so that the eighth level (8) of measurement is in the landfill body, the next seventh level (7) - in the methane distribution layer and six remaining levels at different depths of the methane degrading layer from sixth (6) level to first (1) near the top. The deepest measurement level is $2,07 \mathrm{~m}$ and the top level located at $0,3 \mathrm{~m}$ down the surface. Such construction allows studying degradation rates of methane in the landfill body and also at different levels of layers.

To measure the amount of actual water transpiration three lysimeters were installed at the depths of $0,4 \mathrm{~m}, 1 \mathrm{~m}$ and $1,6 \mathrm{~m}$. The discharge from lysimeters is carried out beyond the boundaries of the experimental cells in special well where six tipping buckets were installed to record water discharge. Online weather station (Davis Instruments, USA) was installed nearby.

Plastic liner was used to separate these two cells from each other, and to prevent gas migration through embankments of experimental cell. The first stage of the isolation construction works was the excavation of trenches around the cells (Fig. 2). The depth of the trench was about one meter. In the trenches, plastic sheets were placed to form a solid rack base for the main insulation and after they were covered with polyethylene sheets (Fig. 3, 4). The height of sheets is about 3 meters and a length is 10 meters. This height is enough to form a continuous isolation in upper and lower part so half of each sheet is located under the surface and another between methane degradation layer and temporary barriers.

The insulation lay with a slight inclination toward embankments. For the integrity and proper placement of the upper part of the insulation, the material on both sides fills up gradually. For corners, ordinary polyethylene and plastic sheet were used. Embankments were constructed with mineral construction and demolition waste with fraction 20 to $40 \mathrm{~mm}$. Approximate amount of materials used for embankment is $280 \mathrm{~m}^{3}$ per cell. 


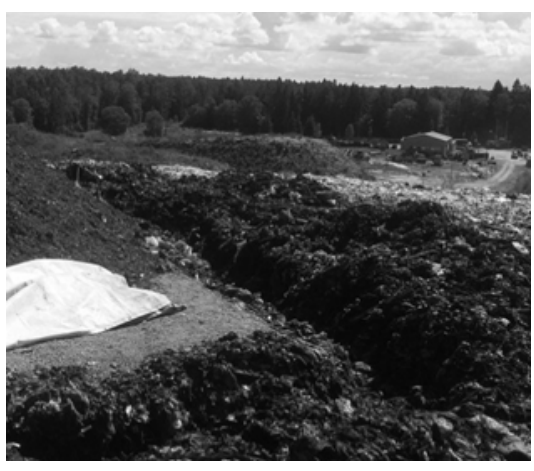

Fig. 2. Excavation of trenches

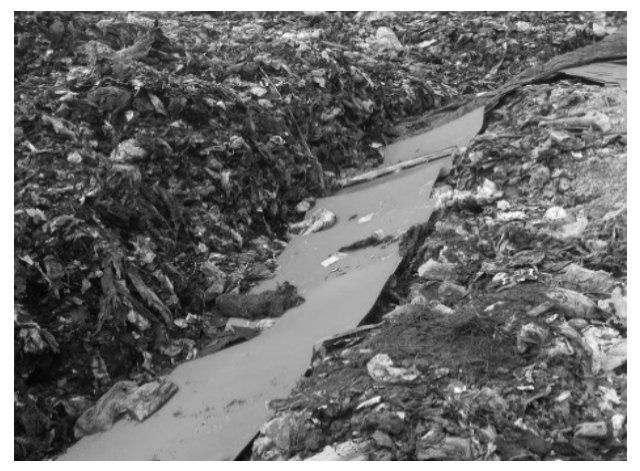

Fig. 3. Plastic sheets for side insulation

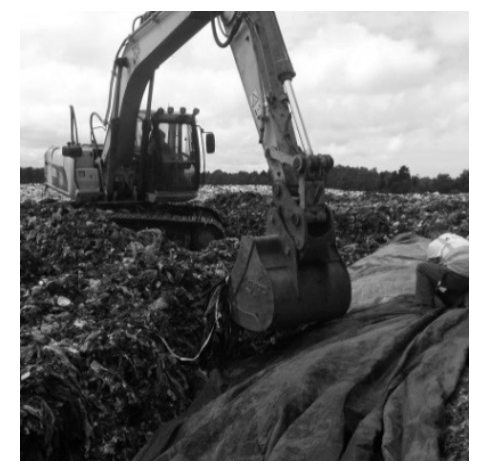

Fig. 4. Polyethylene sheets
The operational properties of the cells were verified by measuring the concentration of methane once a month. Concentration of was measured from both gas well from eight levels by portable gas analyzer GA5000 (Geotechnical Instruments, UK). Measuring the gas at various depths provides information on its distribution, and which the main methane degradation processes undergoes.

For surface gas measurements closed chamber method was used. Three rings for gas chambers per cell with permanent location are used. The concentration of gases was measured in the gas chamber after $0,10,20$ and 30 minutes, by GA5000. Parallel temperature measurement conducted to compare with data on methane gas amount.

Preliminary result and discussion. The part of experimental cell $0-40 \mathrm{~mm}$ fractions was completed in 02.07.2018 and first measurements from gas well were made the same date. The level no 8 is deepest level and level no 1 is close to the surface (labelled as 40,8 and 40,1, accordingly). The second experimental cell with 0-20 mm fractions (labelled as 20,1 and 20,8) was ready by 20.07.2018 and first measurements were made in 24.07.2018. Fig. 5 and 6 show methane concentration measurements at different levels of gas wells.

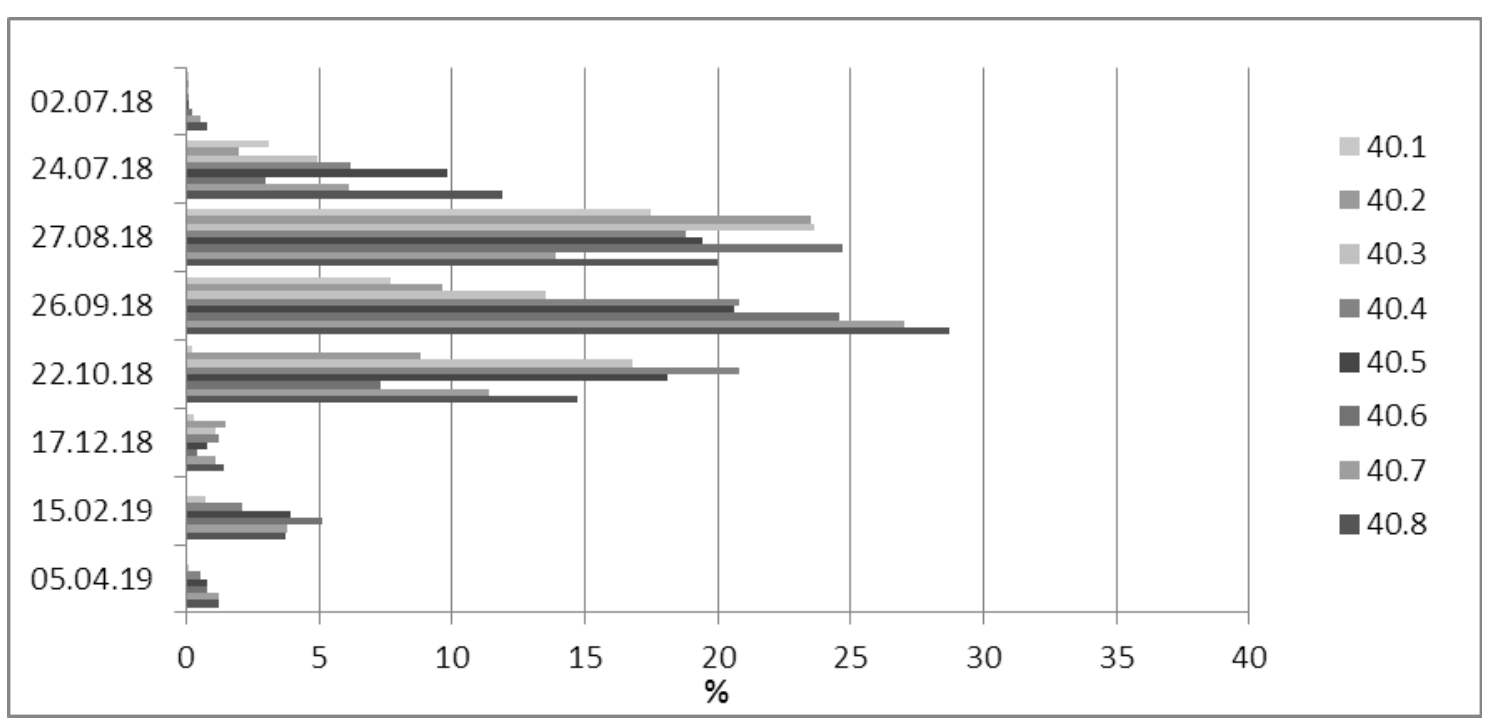

Fig. 5. Methane content in gas cell $0-40 \mathrm{~mm}$

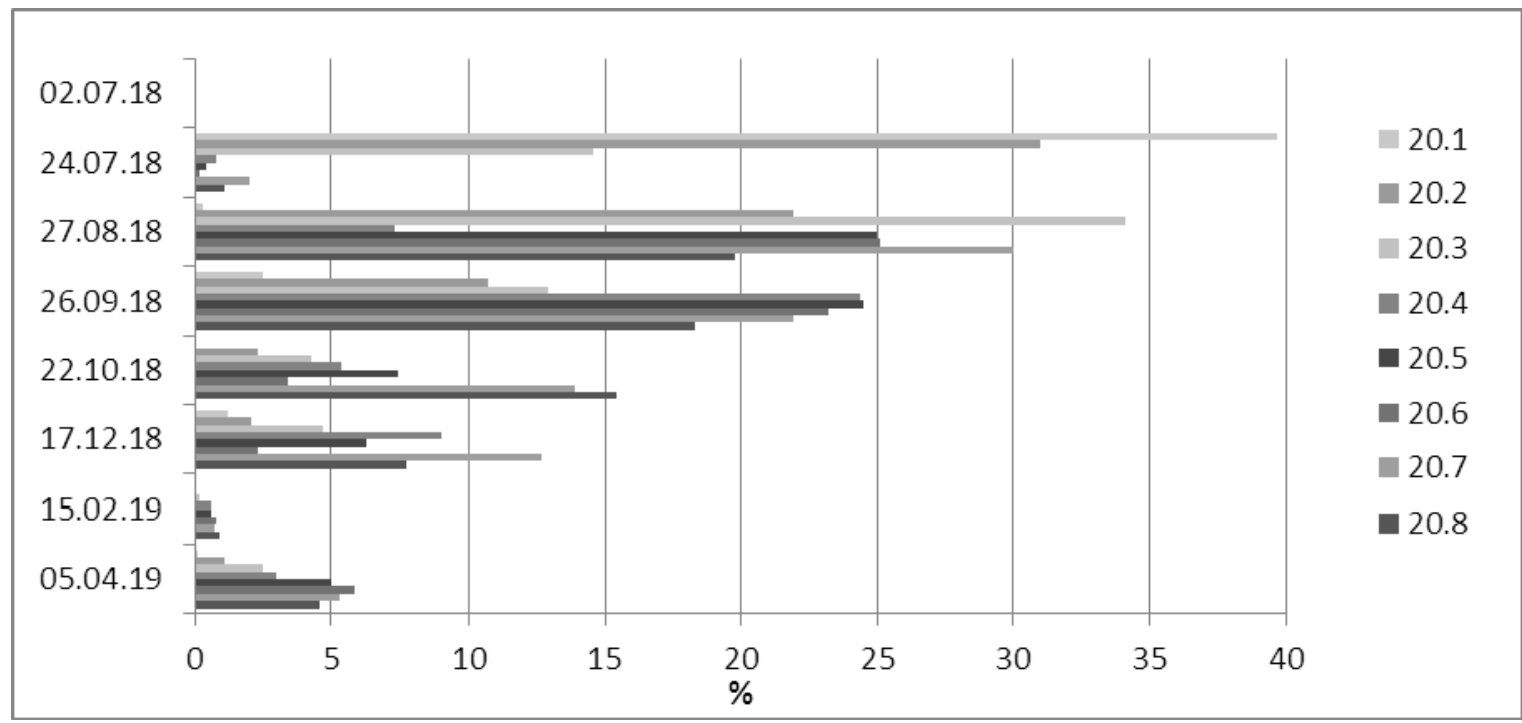

Fig. 6. Methane content in gas cell 0-20 mm 
In both gas cells, methane concentration at 1 level is less than at 8 level, except first measurement in cell 0 $20 \mathrm{~mm}$ due to the fact that at the beginning the construction material has not settled. In general the amount of methane at 8 level increases from July to September for the cell $0-40 \mathrm{~mm}$ and to August for the cell $0-20 \mathrm{~mm}$ and after that it decreases due to lowering the air temperature and frozen landfill surface at winter time [5].

In August and October, the amount of methane at 8-th level is similar in both cells but at first level is less in cell 0-20 mm. In September methane concentration at 1 level is less than at 8-th level in 3,7 times cell in $0-40 \mathrm{~mm}$ and in 7,4 times in cell $0-20 \mathrm{~mm}$. In December situation quite similar, methane concentration at 1 level is less than at 8 level in 4,7 times in cell $0-40 \mathrm{~mm}$ and in 6,4 times in 0 $20 \mathrm{~mm}$. So, based on this result, it can be said, that the cell 0-20 $\mathrm{mm}$ at the present time works a bit more effective than the cell $0-40 \mathrm{~mm}$.

There are no pronounced trends in the distribution of methane in both cells jet. However, there are several similarities. Amount of methane decreases from level 8 to level 5-6, then at level 4-5 sharply increases and then decreases to level 1 in the end of July and December in cell $0-40 \mathrm{~mm}$, in February in cell $0-20 \mathrm{~mm}$ and in October in both. In April, September and at the beginning of July in cell $0-40 \mathrm{~mm}$ amount of methane decreases gradually from 8-th level to first one. And in April, September in cell $0-20 \mathrm{~mm}$ and February in cell $0-40 \mathrm{~mm}$ amount of methane increases from level 8 to level 5-6, then from 45 level decreases to first level, Also, in both cells from September till April methane amount decreases from level 4 to level 1 and is quite unstable from level 8 to 4 .

Conclusion. Landfill gas has a significant impact on the climatic system of our planet due to the high content of methane, which is greenhouse gas. One of the promising options for reducing methane emissions is the coverage of landfill with a bioactive layer. It can be made of various organic-rich materials. In the framework of this project it is planned to check whether fine fraction after mechanical biological treatment (MBT) can be a function material for such biocover. For this purpose two experimental cells were built. Gas emissions are measured in-suit using 8level gas well. Such a system of measurement and cells design allows investigating the movement and dynamics of methane. Preliminary results show that at that time cells work and well simulate biocover. The percentage of methane near the surface is less than in 8 level of gas well. The behavior of methane in cells is different. Further research will show common and distinctive trends in methane distribution and cells efficiency.

Acknowledgements. We acknowledge Uikala landfill staff for helpful hands and assistance with heavy machinery; Swedish Institute funded LASUWAMA project and Estonian basic financed project 8P170055MIVE 'The implementation of the circular economy principles on utilisation of previously deposited waste as resources and energy; and the use of stabilized fine fraction as methane degradation layer to minimise emissions of greenhouse gases.

References:

1. Barlaz, M. A Green, R. B. Chanton, J. $P$, Goldsmith, $C$. $D$. Hater, G. R. (2004). Evaluation of a biologically active cover for mitigation of landfill gas emissions. Environmental Science \& Technology 38: 48914899

2. Crawford J. F., Smith P. G.(1985). Landfill Technology. Wiley, New York,159 P.

3. Hanson, R.S., Hanson,T.E. (1996). Methanotrophic bacteria. Microbiological Reviews 60: 439-471.

4. Hilger, H., Humer, M. (2003). Biotic landfill cover treatments for mitigating methane emissions. Environmental Monitoring and Assessment 84: 71-84.

5. Humer, M., Lechner, P. (2001). Design of a landfill cover layer to enhance methane oxidation - Results of a two-year field investigation. $30^{\text {th }}$ anniversary book. Milestone papers and photostory. Sardinia 2017. $16^{\text {th }}$ International Waste Management and Landfill Symposium. 226-235.

6. IPCC (2014). Climate Change 2014: Mitigation of Climate Change. Contribution of Working Group III to the Fifth Assessment Report of the Intergovernmental Panel on Climate Change [Edenhofer, O., R. Pichs-Madruga, Y. Sokona, E. Farahani, S. Kadner, K. Seyboth, A. Adler, I. Baum, S. Brunner, P. Eickemeier, B. Kriemann, J. Savolainen, S. Schlömer, C. von Stechow, T. Zwickel, J.C. Minx (eds.)]. Cambridge University Press, Cambridge, United Kingdom and New York, NY, USA

7. Pedersen, G. B. (2010). Processes in a compost based landfill biocover; methane emission, transport and oxidation. Kgs. Lyngby, Denmark: Technical University of Denmark (DTU)

8. Pehme, K.-M., Kriipsalu, M. (2018). Full scale project - from landfill to recreational area. Detritus, V. 1. 174-179.

9. Philopoulos, A., Felske, C., McCartney, D. (2008). Field-scale treatment of landfill gas with a passive methane oxidizing biofilter. Journal of Environmental Engineering and Science 7: 531-542.

10. Scheutz, C., Kjeldsen, P., Bogner, J. E., De Visscher, A., Gebert, J., Hilger, H. A. (2009). Microbial methane oxidation processes and technologies for mitigation of landfill gas emissions. Waste Management Research 27: 409-455.

Надійшла до редколегії 07.05.19

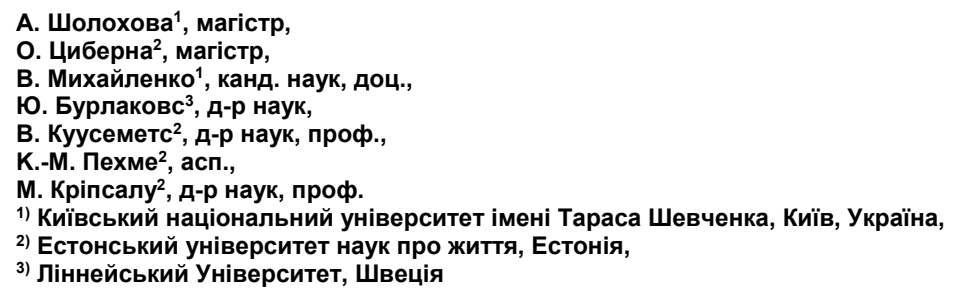

\section{ПІЛОТНЕ МЕТАНОДЕГРАДУЮЧЕ БІОПОКРИТТЯ НА ДІЮЧОМУ ПОЛІГОНІ}

Полігон твердих побутових відходів (ТПВ) - це великий біореактор, у тілі якого утворюються звалищні гази. Основним компонентом звалищних газів є метан, який утворюється в результаті анаеробної деструкції органічних фрракцій. Викиди метану заідно з європейським законодавством повинні бути зведені до мінімуму, оскільки він є парниковим газом і значно впливає на зміну клімату планети. У процесі генерації великих обсягів метан може бути використаний для виробництва енераії, але якщо продуктивність метаноутворення падає, перспективним варіантом мінімізації викидів є накриття полігону біоактивним шаром, який руйнує метан у товщі накриття. На діючому санітарному полігоні Уйкала (Естонія) існує система збору біогазу, однак за рахунок горизонтальної дифузії не весь газ уловлюється даною системою. Емісію метану з полігону можна знизити иляхом його біодеструкції в товщі накриття. Метою даної роботи є перевірка ефективності роботи двох пілотних майданчиків, сформованих на основі тонких фракцій, отриманих після механічної та біологічної обробки відходів (МВT). 3 цією метою були побудовані два експериментальні майданчики, накриті фракціями різної крупності: 0-20 мм і 0-40 мм. Нами представлено проект конструкції майданчиків, описано процеси їхнього будівництва, властивості будівельних матеріалів і попередні результати дослідження. Системи моніторингу емісії метану в товщі накриття встановлені на обох майданчиках: газові свердловини із фільтрами розміщені на восьми рівнях і три газові камери облаштовані на поверхні обох майданчиків. Для контролю водного балансу в товщі накриття встановлено три рівневі лізиметри. Дослідження біодеструкції метану заплановано терміном на два роки із щомісячним виміром емісії метану на кожному з рівнів. Завданням експерименту є визначення ефективності біодеструкції метану залежно від крупності фракцій МВТ: 0-20 мм або 0-40 мм. Підтвердження ефективності накриття більш дрібною фрракцією МВТ важливо не тільки з екологічної, але й технологічної точки зору. Застосування дрібної фракції відходів як будівельного матеріалу для створення шару біопокриття зменшить витрати на переробку цієї фракції і стане хорошим прикладом кругової економіки, оскільки в процесі рекультивації полігону планується використання власних ресурсів.

Ключові слова: звалищні гази, метан, фракція МВТ, емісія, біодеструкція метану, накриття полігону, лізиметр. 
А. Шолохова ${ }^{1}$, магістр,

А. Циберная ${ }^{2}$, магістр,

В. Михайленко ${ }^{1}$, канд. наук, доц.

Ю. Бурлаковс ${ }^{3}$, д-р наук,

В. Куусеметс ${ }^{2}$, д-р наук, проф..

К.-М. Пехме ${ }^{2}$, асп.

М. Крипсалу' ${ }^{2}$ д-р наук, проф.

1) Киевский национальный университет имени Тараса Шевченко, Киев, Украина,

2) Эстонский университет наук о жизни, Эстония,

3) Линнейский Университет, Швеция

\section{ПИЛОТНОЕ МЕТАНОДЕГРАДИРУЮЩЕЕ БИОПОКРЫТИЕ НА ДЕЙСТВУЮЩЕМ ПОЛИГОНЕ}

Полигон твердых бытовых отходов (ТБО) - это большой биореактор, в теле которого образуются свалочные газы. Основным компонентом свалочных газов является метан, который образуется в результате анаэробной деградации органических фракций. Выбросы метана согласно европейскому законодательству должны быть сведены к минимуму, поскольку он является парниковым газом и значительно влияет на изменение климата планеты. При генерации больших объемов метан может быть использован для производства энергии, но если производительность метанообразования падает, перспективным вариантом минимизации выбросов является накрытие полигона биоактивным слоем, который разрушает метан в толще биопокрытия. На действующем санитарном полигоне Уйкала (Эстония) существует система сбора биогаза, однако за счет горизонтальной диффузии не весь газ улавливается данной системой. Эмиссию метана с полигона можно снизить путем его деструкции в толще биопокрытия. Целью данной работь является проверка эффективности работы биопокрытий, сформированных из мелких фракций, полученных после механической биологической обработки отходов (MBT). С этой целью были построены две экспериментальные площадки, накрытые фракциями различной крупности: 0-20 мм и 0-40 мм. Нами представлен проект конструкции площадок, описаны процессы их строительства, свойства строительных материалов и предварительные результаты исследования. Системы мониторинга эмиссии метана в толще покрытия установлены на обеих площадках: газовые скважины с фильтрами размещены на восьми уровнях и три газовые камеры обустроены на поверхности обеих площадок. Для установления водного баланса в толще покрытия установлены трехуровневые лизиметры. Исследование биодеструкции метана запланировано сроком на два года с ежемесячным измерением эмиссии метана на каждом из уровней. Заданием эксперимента является определение эффективности деградации метана в зависимости от крупности фракций МВТ: 0-20 мм либо 0-40 мм. Подтверждение эффективности накрытия более мелкой фракции МВТ важно не только с экологической, но и технологической точки зрения. Применение мелкой фракции отходов в качестве строительного материала для создания слоя биопокрытия уменьшит расходы на переработку этой фракции и станет хорошим примером круговой экономики, поскольку в процессе рекультивации полигона планируется использование собственных ресурсов.

Ключевые слова: свалочного газы, метан, фракция МВТ, эмиссия, биодеструкция метана, накрытие полигона, лізиметр.

\section{СТРУКТУРНО-ГЕНЕТИЧЕСКИЕ ОСОБЕННОСТИ И ТЕНДЕНЦИИ РАЗВИТИЯ ЛАНДШАФТОВ ЗОНЫ ПРИКАСПИЙСКИХ РАВНИН (ЮГО-ВОСТОЧНО-ШИРВАНСКОЙ, САЛЬЯНСКОЙ И ЛЕНКОРАНСКОЙ)}

Дана характеристика двух основных групп факторов, влияющих на современную динамику ландшафтов: природных и антропогенных. Участвующие в динамике ландшафта антропогенные факторы отличаются большей интенсивностью, чем природные. Природные факторы в основном определяют направленность динамики ландшафтов. В структурно-генетическом отношении современное состояние ландшафтов зоны прикаспийских равнин отличается исключительной динамичностью и интенсивно возрастающей антропогенной нагрузкой. В целом прибрежные равнинные ландшафты исследуемой территории, вышедшие из-под воды в недалеком прошлом, в связи с поздними геолого-геоморфологическими процессами имеют сравнительно молодой плейстоцен-голоценовый возраст.

Составлены графики изменения годовых величин атмосферных осадков за многолетний период (1873-2000) по некоторым метеостанциям исследуемой территории в сопоставлении с приростом годичных колец деревьев (17602005). Анализ графиков показал, что, несмотря на ежегодные отклонения величин атмосферных осадков от нормы, 6 многолетнем ходе можно проследить тенденцию к их уменьшению. Сопоставление изменения атмосферных осадков с динамикой годового прироста древесины многолетних деревьев, срубленных в лесном ландшафте Ленкоранского низкогорья, которые ближе расположены к прикаспийским равнинам, показало наличие между ними прямой корреляции.

Нами проанализированы ландшафтные последствия в основном трех периодов колебания уровня Каспийского моря: первый период снижения уровня моря (1877-1977), второй период повышения уровня моря (1977-1998), третий период снижения уровня моря (после 1998 г).

В первый период уровень грунтовых вод в прибрежных болотных, болотно-лvrовых, болотно-лагунных комплексах понизился, водный режим почв ухудшился, и получили развитие полупустынные и сухостепные растительные группировки. Во второй период повышения уровня моря (1977-1988) происходит значительное ослабление вышеуказанных процессов, а в некоторых местах прибрежные комплексы остались практически под водой, в целом изменилась вся экологическая обстановка в природно-территориальных комплексах. В последний третий период происходит уменьшение акватории Каспийского моря и увеличение площади континентального режима развития ландшафтов.

Установлена приуроченность некоторых специфических элементов ландшафта к районам погребенных поднятий. Более интересным в этом отношении являются прогрессивное осушение отдельных участков аллювиальноозерно-старичных равнин под влиянием локально проявившихся восходящих тектонических движений, линейное распространение голофитной растительности и такыровидных солончаков вдоль зоны выхода засоленных подземных вод по тектоническим разрывам, скопление зарослей древесной растительности на погруженных поднятиях участков речных долин.

После осуществления огромных мелиоративных мероприятий на поверхности территории хорошо выражены антропогенные формы рельефа: искусственные гряды, понижения, холмы, террасы, овраги, коллекторно-дренажная сеть и др. На орошаемых территориях густота искусственного расчленения рельефа местами достигает 4,55,5 к/км, әлубина расчленения изменяется от 0,8 до 3,5 м.

За последние 100 лет лесистость Ленкоранской низменности уменьшилась почти в 4-5 раз. Коренные изменения лесных площадей Ленкоранской равнин и замена их однотипными агроценозами или лесонасаждениями, состоящими из одной-двух древесных пород (каштанолистый дуб, сосна, тополь и др.), значительно усилили интеграцию видового состава и ярусной структуры растительного покрова. 